\title{
Servant Leadership Model as Catalyst in Strengthening Character Education: An Exploration Study of Principal's Leadership in Sumbawa Regency Indonesia
}

\author{
Sudirman Wilian* \\ Graduate Program of Educational Administration \\ Universitas Mataram \\ Mataram, Indonesia \\ sudirman_wilian@unram.ac.id \\ Untung Waluyo \\ Graduate Program of Educational Administration \\ Universitas Mataram \\ Mataram, Indonesia
}

\author{
Muntari Muntari \\ Graduate Program of Educational Administration \\ Universitas Mataram \\ Mataram, Indonesia \\ I Wayan Karta \\ Graduate Program of Educational Administration \\ Universitas Mataram \\ Mataram, Indonesia
}

\begin{abstract}
During the last two decades, character education policy has become a major issue in Indonesia. To implement the policy properly, principals are required to be able to integrate character education into curricular, intra-curricular and extracurricular activities in schools. These ideal conditions, however, are not much known as little is reported about the contribution of the principal's leadership to the implementation of character education policies. The current study aims to uncover the Principal's strategic leadership models in Sumbawa Regency in enhancing their potentials to implement character education policies in schools. A qualitative research design with a multi-case study approach was utilized as a basis for collecting, analyzing and comparing data from this study. The procedures and stages of activities undertaken in this study include collecting preliminary data on various leadership models through observation, interviews and document studies. Data analysis involves data reduction, data display and conclusion drawing. Results of the study succinctly report that a number of school principals developed innovative leadership models based on religious values and self-efficacy. From this research, a description of success factors and impeding factors that affect the application of character in schools is obtained.
\end{abstract}

Keywords - character education, servant leadership, school principal

\section{INTRODUCTION}

Character building and student's moral development at schools have become a central issue in the last few decades. A number of education experts maintained that the development of character building is the elemental capital for the students to build their nationalism and the value of their nationality [1], [2], [3], [4], [5].

Indonesian has basically been inherited the religious noble values from their ancestors for ages. These heritages have become important parts of the national development in which the learning center does not only take place at schools but also at the family homes [6] [7]. In line with this, Watson [8] stated that moral education has long life effect on the young generation. Hence, character building and national identity through education needs to be instilled as early as possible and directed at building of the moralities and values in accordance with the noble ideals of the nation.

The morality and the noble values of the Indonesian above are grounded on religious teaching, the five principles philosophy and cultural values of the people [9]. These are the three essential components that play significant roles in the Indonesian human character building as prescribed in the national education goals. Hence, the three components must be integrated into the domain of the Indonesian children education as early as they possibly could, geared to the accomplishment of the national education vision, namely to become the one humanized whole human being of Indonesia. Therefore, those morality and noble values must be taught through integrated nurturing, either in schools, family, or in society implemented through real daily examples of good behavior and code of conducts.

Basically, character education development does not only teach educational moral values at school but also the practices outside school as well as the willingness to create similar moral ethos and educational environment for students who hold different religion and faith. In order for the character education to be implemented in the students' everyday-real life, nurturing milieu for learning together should be provided. The concept of student active learning for character education must be focused to provide students with opportunity to get involved in the activities focusing on building exemplary character. Therefore, school as learning organization has the responsibility to promote education character as mandated by the character education movement itself.

In order that character education could run well at schools, principal as an organizational leader is required to be able to influence teachers and administration staffs to guard the implementation of character education. Senge [10] argues that school can become a learning organization if its principal could engage with all stakeholders to work together, applying principles of learning together consistently. In a learning organization, a visionary school principal will always be committed to creating changes and 
will work together with all parties as well as accept all people in the organization in any condition. This attitude will encourage all stakeholders to willingly seriously help principals manage the resources available at schools. They can work together and build commitment to implement already-agreed-upon policy and create school climate that would make everybody feel comfortable and happy.

Within a school that applies learning organization, the burden of a principal facing the complexity of school system could be decreased, and so could the other stakeholders. A school principal sharing similar vision with others commonly could build its school cultural organization consistently allocating the available resources, and communicating its strategic view on and on.

According to Northouse [11], a principal who has a vision of a strategic leader commonly favors being put at schools with full of challenges and works within a complicated environment. In this type of school, a principal usually faces a plenty of problems. The action he or she would take would be rooted on efforts to build school as a learning organization for every individual in it and therefore they would be involved in it too. He would directly apply egalitarian attitude to develop equality with all colleagues. This typical school leader realizes that everyone has its own important role that could directly influence the results to be achieved by the school as a learning organization. Realizing his weaknesses, a strategic leader would always involve more people in managing the available resources [12].

In relation to this, Senge [10] in his book "School that learns" states that school in this millennial era could move on and develop gradually not through a forceful set of regulation or command but through the implementation of a shared system of learning. If everyone under the school institution could express aspiration, build awareness, and improve self-capacity cooperatively, school advancement involving all stake holders could be achieved well. According to Senge, every school component such as teachers, principal, and other stake holders should learn to develop self-competences through collective learning improvement in the organization. A real change could only happen if every component in the school is committed to make changes collectively. If a school could become a place of learning organization, everyone can contribute to make common changes by maintaining a healthy, cultured and nurtured organizational climate.

\section{METHOD}

This research was carried out at the Regency of Sumbawa, West Nusa Tenggara, Indonesia, and the reason of which was that this regency was used as a pilot project for the socialization and training implementation of the character education affirmation movement. As such, it was estimated that the average schools in this area had done the implementation of character education at Junior High Schools. Therefore, the researchers wanted to find out further the effect of that socialization and training on the implementation of character education within junior high schools in Sumbawa. It also aims at discovering the strategic approach model used by principals in making the character education movement effective at schools. For the purpose of this research, 4 schools representing all schools from the 4 sub-districts in Sumbawa Regency were chosen.
Qualitative research method was then applied to carry out this research considering that the issue of principal's strategic leadership and its impact on the implementation of a policy has complexity that cannot be represented by merely statistical figures. To be able to comprehend a more complicated problems a school principal faces in applying a policy at his school, qualitative method using case study is required. Punch [13] illustrates that a case study approach is appropriate to use to reveal a complicated phenomenon in education sphere employing various sources of data. Therefore, to collect, analyse and compare the data, this research used multi-case studies, expecting that the researchers were able to explore a number of schools chosen in Sumbawa Regency that have implemented character education movement along with the strategic leadership model employed by the principals to drive stakeholders' participation that goes well with the Education Department Regulation No. 20/2018.

The procedures and steps of research activities encompassed collecting initial data concerning character education movement implementation at the 4 schools selected, followed by interview with principals, and FGD (Focused Group Discussion) with teachers in searching for their perceptions on the principals' effort in implementing character education movement. The data from various sources were then analysed using qualitative analysis procedure as suggested by Miles and Huberman [14], consisting of reducing data, presenting data, drawing conclusion and finally verifying. Data from observation were classified and selected based on the theme appeared. And so is the data from the interview, they were selected based on the theme and category appeared. In short, the data which were relevant with the theme were classified into subsub theme until they reached saturation (Miles and Huberman, 2005).

Similar procedures were held for the results from teachers focused-group discussion and documentation analysis in order to see the consistence of leadership implementation pattern at schools. The triangulation data analyses were used to obtain and strengthen the degree of data reliability and validity, so that the description of success and impeding factor of the character education movement implementation could be discovered and the lesson learnt model could be drawn.

\section{RESULTS AND DISCUSSION}

The results of the study reveal that all participating school principals have developed servant leadership with its own uniqueness. The principal of Junior High School 01 (SMP01) explicated that he developed an open attitude to work together with community, formal institutions, and with parents collaboratively in designing character education movement at his school. He explained that "for giving information about preventive action, such as traffic regulations, legal problem, drug abused, and so on, I would invite related institution to come to have a discussion with our students". He admitted that he cannot work alone. Therefore, he would invite all components in and out of the schools to take part supervising the implementation of character education in his school. A number of the school teachers interviewed said that the principal of SMP-01 always come earlier than the teachers. "He is always waiting for us at the school gate only for shaking hands and 
welcoming us," said one of the teachers. Other teacher also added that "our principal doesn't like formalities. Very often he carries over flag ceremony equipment himself if he comes earlier."

According to some teachers, the principal of SMP-01 also demonstrated his competence creating positive school culture for both teachers and students. One of them described that "our principal introduced the discipline movement to our students by not riding motorcycle and not bringing mobile phone to school." This policy is aimed to prevent students from having traffic accident and mobile phone abused at school. In order to be fair, the principal also requires teachers not to use phone in the classroom. He admitted that this school regulation was accepted by all teachers and other stakeholders, including student parents.

This study also reveals that principal of Junior High School 02 (SMP-02) of Sumbawa developed a broad vision in managing school resources. Even though his explanation is different from his colleagues, this principal mentioned a number of similar key concepts dealing with servant leadership he is caring, that is deference towards others, consistency with honesty, open communication, commitment towards job, prioritizing teacher's welfare, and upholding tolerance. In managing school facilities and infrastructures, for example, the principal of SMP-02 is fully responsible for and fair with staffs. Within this shared responsibility, every member of school community feel obliged to maintain school facilities together.

Findings from interview with teachers of SMP-02 indicated consistency of data that the majority of teachers feel positive towards the leadership style of their school principal who prioritized giving services to everyone. According to them, their principal has appropriate leadership capacity to lead their school. They consider the principal servant attitude as an important component of a school leadership culture, leading by example in the front as Javanese saying goes "ing karso sung tulodo".

From the interview with the principal of SMP-03, it was found that he generally got teachers and students' parents involved in supervising the school budgeting. "To avoid prejudice, I periodically reported the budgeting condition to parents and other stakeholders," said the principal of SMP03. The action the school principal took is a collective supervision strategy to avoid corruption or prejudice towards any service and activity. The average teachers who were interviewed gave similar response with their principal's statement. "Our school principal applied a number of initiations to manage the school budget professionally. $\mathrm{He}$ has open minded and transparent over the school budgeting problem."

In addition, according to them, this school principle frequently took a surprising initiative carrying out his task as a supervisor. "He often came into classroom with no teachers in the first period", said one of the teachers. "Once it happened to me because I came late. I was so ashamed and promised to my- self not to come late again." With the exemplary that he is showing in real terms, principal of SMP03 is slowly building discipline at school together. "My job is only helping teachers if they are having problems," he said. "If I were to find a problem with teacher's teaching performance, I encouraged them to have self-evaluation and self-reflection. I am always open to accept their complaint." This kind of approach makes teachers feel convenience, safe, and open-minded to discuss whatever problems they face.

The school principal of Junior High School No-4 (SMP04) also demonstrated similar leadership behavior. $\mathrm{He}$ confessed that teacher composition in his school is heterogeneous, both in terms of ethnicity or faith. Therefore, principal is demanded to serve them fairly and equally. He is supposed to be able to maintain fairness and openness in giving tasks to every staff. In the same manner, teachers who were interviewed claimed that their principal is 'too kind hearted' to everybody. Because of his 'servant leadership attitude' he has slight constraint communicating with few senior teachers who showed unfavorable attitude towards his leadership style. "Our principal is relatively young. He has tried to involve fairly all teachers and administrative staffs in managing both curricular and non-curricular activities at schools," said one of the teachers. "But some of us still show sort of unfriendly attitude towards the principal's leadership style." This finding indicates that seniority, experiences, and carrier stages affect teacher's attitude and responses towards his leader.

Almost all teachers from all schools commented positively about their school principals. They mentioned some amount of individual quality they possessed, namely modest, servant minded, fair, open, and professional. The teachers said that by servant leadership model, their principals could build a convenient work environment that was acceptable by everyone. They also described their principal leadership as bringing in a warm familial school environment. They confessed that their principals applied the effect of servant leadership astonishingly.

Broadly speaking this research reveals three important outcomes regarding school principal leadership style in the 4 schools being studied: first, the principals act as servant; second, they developed shared learning climate to improve positive mutual respectfulness; third, they applied stewardship, leading by giving example, the servant-leader not power-leader.

\section{CONCLUSION}

This study concludes that (1) the implementation of servant leadership model by the chosen school principals in Sumbawa Regency contributes positively toward the government effort to carry out character education enforcement movement; (2) successful factors supporting principal leadership to implement character education enforcement was identified based on their abilities to build equal human relationship, collaborate with all parties, develop exemplary attitude, and prioritize teachers' and all staffs' necessities and well-being. While there are differences in leadership style, all the principals from the 4 schools in this region was showing similar leadership principles and styles in managing the schools, building personal and interpersonal relationship in their-everyday human life practices.his study has developed the teaching aids accompanied with instructions which can be used to determine the areas of triangle and kite. These teaching aids are very suitable for elementary school students. By providing instructions on how to use these teaching aids, the 
information or teaching material delivered to the students will be consistent in results even though they are used by different teachers.

For elementary school teachers who will use these teaching aids, it is better for them to have in-depth knowledge about the material they are going to teach. Mathematic teachers can change or simplify the mathematical terms to be easily understood by students however this is not to ignore the essential or the meaning of these terms. Teachers who are interested in using these teaching aids should have or explore the adequate prerequisite knowledge.

\section{ACKNOWLEDGMENT}

Final draft of this research article wouldn't have been possible without the generous funding assistance from the Rector of Universitas Mataram through the University of Mataram Research and Community Service Center (LPPM). Therefore, the research team gratefully acknowledge the head of LPPM upon the grant received via contract number: 1459.W / UN18.L1 / PP / 2018, Universitas Mataram.

\section{REFERENCES}

[1] S. I. Dwiningrum. 2013. "Nation's Character Education Based on the Social Capital Theory". Journal Asian Social Science, 9 (12): 144-155

[2] T. M. P. Astuti, K. Elly, \& B.F. Kuncoro. 2014. The Socialization of Model Character Education for Students in Elementary School Trough Comic. Jurnal Komunitas, 6(2), 260- 270. Retrieved from https://journal.unnes.ac.id/nju/index.php/ko munitas1/article/view/3305

[3] S. Rustiadi, 2015. Creating Better Education System, Building Stronger Human Capital: A Creative Industries Perspective. Procedia - Social and Behavioral Sciences. $169 . \quad 378-386$. 10.1016/j.sbspro.2015.01.323

[4] S. Sumarni, A. Dardiri, \& D. Zuchdi, D. 2015. Pengembangan Mode Pendidikan Karakter Berbasis Penguatan Modal Sosial Bagi Mahasiswa UIN Sunan Kalijaga. Jurnal Pembangunan Pendidikan: Fondasi Dan Aplikasi, 3(1), 44-57.

[5] W. Wahyutiningsih. 2017. Character Education as the Place for Shaping the Morality of Children of the Nation. International Conference on Education (IECO) Proceeding, Vol. 1, P. 314-323

[6] J. Subianto. 2013. Peran Keluarga, Sekolah dan Masyarakat Dalam Pembentukan Karakter Berkualitas. Edukasia: Jurnal Penelitian Pendidikan Islam, 8(2), 331-354

[7] A. Syarbini. 2014. Model Pendidikan Karakter dalam Keluarga. Jakarta: PT Elex Media Komputindo

[8] M. Watson. 2006. Long Term Effect of Character/Moral Education. Journal of Research in Character Education . Vol. 4 Issue 1/2, p1-18. $18 \mathrm{p}$.

[9] B. Maunah, Implementasi Pendidikan Karakter dalam Pembentukan Kepribadian Holistik Siswa, Jurnal Pendidikan Karakter, Tahun V 2015. No. 1, h.92

[10] P. M. Senge. 2000, Schools that learn: A fifth discipline field-book for educators, parents and everyone who cares about education. New York: Crown Business.

[11] Northouse, P. G., 2010, Leadership: Theory and practice. California: Thousand Oaks,

[12] P. Senge, C. Roberts, R. Ross BJ. Smith dan A. Kleine. 2010, The fifth discipline field-book. (4h Ed,). London: Century Pub.

[13] K. F. Punch, 2009.. Introduction to Research Methods in Education. London: SAGE Publications

B. Miles, Matthew \& M. Huberman..1994..Qualitative Data Analysis.SAGE Publications 